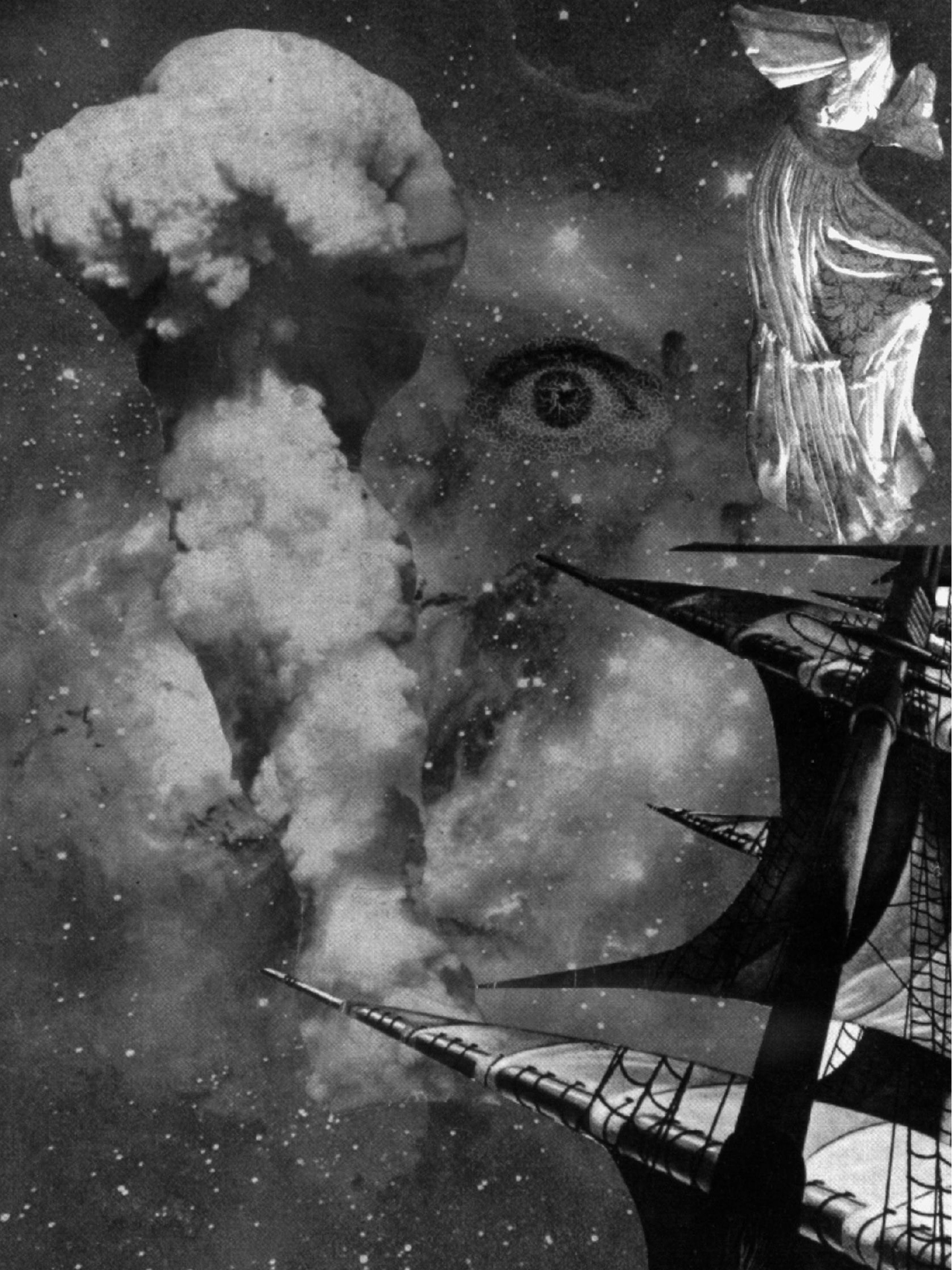




\section{Tadeu Chiarelli A FOTOMONTAGEM COMO “INTRODUÇÃO À ARTE MODERNA": VISÕES MOERNISTAS SOBRE A FOTOGRAFIA E O SURREALISMO}

Crítico de arte e professor do Departamento de Artes Plásticas da Escola de Comunicações e Artes da Universidade de São Paulo.

O propósito deste texto é levantar alguns problemas sobre a questão da fotografia durante o período de apogeu e ocaso do modernismo brasileiro, mais especificamente, sobre a prática da fotomontagem por artistas modernistas durante aqueles anos.

Tal propósito, de alguma maneira, vai ao encontro da necessidade de se ampliar o debate sobre a história da fotografia no Brasil, tendo em vista os raros estudos nesse setor, capazes de abrir novas possibilidades para se pensar a produção dos artistas e intelectuais modernistas no quadro das transformações que os novos meios tecnológicos causavam no cotidiano brasileiro.

Como é do conhecimento de todos, no campo das artes visuais, a corrente hegemônica do modernismo visou constituir um imaginário nacional, pautado na glorificação do homem brasileiro'. Esta tomada de posição de caráter ético e político, imediatamente determinou um posicionamento estético que alijou do debate artístico local duas questões que marcaram as vanguardas européias do início do século $\mathrm{XX}$, retirando do modernismo brasileiro a possibilidade de ser estudado como um simples desdobramento das mesmas, aqui abaixo do Equador. Em primeiro lugar, a necessidade de constituição de um imaginário nacional, onde o "homem brasileiro" fosse o protagonista, deixou imediatamente de lado toda possibilidade de ser desenvolvida no país qualquer poética que se desprendesse da necessidade de figurar esse "homem brasileiro", sempre de maneira positiva. Obedecendo tal proposição, todo o desenvolvimento da produção gráfica, pictórica ou escultórica tendente à nãofiguração foi excluída do âmbito modernista.

Entre o final da segunda década do século XX e o final dos anos 40, os raros artistas que timidamente enveredaram para a abstração - ou mesmo para poéticas figurativas pouco ou nada aderentes à figuração positiva do "homem brasileiro" -, foram devidamente desencorajados ou relegados a um plano secundário dentro do panteão modernista ${ }^{2}$.

Em segundo lugar, nessa opção de criar tal imaginário brasileiro, não cabia o uso de modalidades artísticas ainda não consagradas.

Para o artista local ser de fato reconhecido e autorizado pelo modernismo hegemônico da primeira metade do século passado, era necessário que ele, além de enaltecer a paisagem humana brasileira dentro de moldes “aceitáveis" de deformação expressiva se valesse, para tanto, das modalidades tradicionais: desenho, gravura, escultura e pintura.

\footnotetext{
1. Entendo por "corrente hegemônica" do modernismo brasileiro, aquela que, encabeçada por Mário de Andrade no

terreno da crítica de arte, constituiu um projeto para a produção visual brasileira, projeto este aceito e levado adiante por vários intelectuais, artistas plásticos $e$ arquitetos, obtendo o apoio do governo federal, entre a década de 30 e a seguinte.
}

2. Sobre o assunto ler, entre outros: TADEU

CHIARELLI. De Almeida Jr. a Almeida Jr.: a crítica de arte de Mário de Andrade. Tese de Doutorado. São Paulo, ECA-USP, 1996. 
3. Caso da produção fotográfica de Mário de Andrade, a ser comentada logo à frente.
Outras modalidades de construção de imagens nunca foram efetivamente valorizadas. Durante o modernismo não foi dada nenhuma importância decisiva à exploração estética da fotografia ou do cinema, por exemplo.

Experiências no campo da fotografia tenderam a ficar quase sempre no âmbito do privado3. Por sua vez, propostas ainda mais radicais, que tentassem unir modalidades artísticas até pouco tempo estanques ou mesmo que rompessem com a dicotomia arte/vida foram constantemente ignoradas.

Consciente que este não é o espaço ideal para adentrar nas razões que levaram essa corrente vencedora do modernismo brasileiro a alijar tais questões do debate artístico da primeira metade do século passado, creio que seria oportuno, no entanto, apenas levantar alguns problemas que talvez ajudassem a começar a entender tal situação.

Em primeiro lugar, creio que o dado mais importante para que as especulações estéticas modernistas nunca tenham se afastado da necessidade de figurar o homem brasileiro - constituindo assim um suposto imaginário nacional -, tenha sua origem no debate artístico local, iniciado no século XIX, onde, desde o início, a questão do nacional na arte era um problema a ser enfrentado.

Para os modernistas, esse problema continuava como primordial dentro do quadro do debate artístico-cultural do início do século $\mathrm{XX}$, e deixá-lo de lado, em prol de especulações estéticas e artísticas que tendiam a romper o estatuto da arte como representação mais ou menos idealizada do entorno (ou mesmo propusessem a penetração definitiva da arte no território da vida), era desviar-se de um dever quase sagrado.

Uma vez que acreditavam que no século anterior a arte brasileira tinha deixado sua obrigação ético-estética de eternizar o homem brasileiro e sua realidade - preferindo o enaltecimento do poder imperial e/ou a propriedade burguesa -, caberia a eles, modernistas do início do século XX, levar a cabo aquela missão. Para que tal intenção pudesse ser cumprida, muito cooperou o fato do modernismo brasileiro ter surgido, efetivamente, quando a arte internacional passava por uma séria transformação, onde o ímpeto iconoclasta das vanguardas dos primeiros anos do século passado vinha sendo abatido por uma série de manifestações conservadoras que visavam recolocar no debate e na prática artística certos valores tidos como "eternos".

O modernismo brasileiro, quando surgiu "oficialmente" no início dos anos 20, tinha duas possibilidades a seguir: Ou dava prosseguimento aqui no Brasil às correntes das vanguardas européias do início do século, que problematizavam esteticamente todas as transformações da vida contemporânea, (transformações políticas, econômicas, tecnológicas e culturais); Ou fazia tábula rasa dessas questões, voltando-se em direção ao então "novo" retorno à 
ordem internacional.

O modernismo local, sem dúvida alguma, optou pela segunda possibilidade, pois, aderindo ao retorno à ordem, acreditou que - finalmente! - poderia constituir no Brasil um imaginário local. Um imaginário nacional, baseado na representação da paisagem humana do país, repleto, sem dúvida, de estilemas de derivação vanguardista, porém sem nenhum vislumbre de radicalização formal que comprometesse essa sua meta principal. Neste contexto tão peculiar, a fotografia foi usada de maneira muito esporádica pelos modernistas e, na maioria das vezes, simplesmente como atividade periférica àquela principal, quer fosse a pintura, a poesia ou a literatura ${ }^{4}$.

Sabe-se muito pouco sobre o uso da fotografia por artistas e intelectuais modernistas. Questão que até hoje pouco interessou aos historiadores e críticos deste movimento, fica bastante dificil saber se, de fato, houve algum tipo de produção mais consistente neste campo, ou se o uso da fotografia pelos protagonistas do modernismo não passou de mera atividade de lazer, sem maiores conseqüências no campo de suas preocupações estéticas.

Até o momento, ao que parece, a produção fotográfica mais conhecida do grupo modernista, é aquela produzida pelo escritor e crítico Mário de Andrade, sobretudo durante suas viagens pelo interior do Brasil.

Segundo Telê Ancona Lopez, Mário de Andrade começou a fotografar a partir de 1923, ano em que passa a assinar a revista alemã especializada em fotografia Der Querschnitt (coleção que vai até 1932).

Por meio dessa publicação, o crítico se familiariza com os fotógrafos ligados à Nova Objetividade Alemã, fotógrafos autorais, preocupados não apenas em documentar o real mas, igualmente, na constituição de uma linguagem fotográfica autônoma, pautada no corte, no close, na ênfase nos contrastes de preto e branco, etc ${ }^{5}$.

Para a autora, a parte principal da produção fotográfica do crítico será realizada durante suas viagens à Amazônia (1927), e ao Nordeste brasileiro (1928). Após essas duas experiências mais grandiosas - onde produz fotografias de grande interesse, onde une, com um olhar muito especial, o estético e o documental -, Mário de Andrade vai aos poucos deixando de lado a sua atividade como fotógrafo, em 1931. Com mais de setecentas unidades, e com elementos, como foi dito, de forte interesse estético e documental, a produção fotográfica de Mário de Andrade apenas na última década passou a ser mais sistematicamente estudada e até o presente aguarda novos aprofundamentos.

A partir da publicação do livro Flávio de Carvalho: o comedor de emoções, do artista e estudioso $\mathrm{J}$. Toledo ${ }^{6}$, vieram à luz algumas produções fotográficas de Flávio de Carvalho, produções essas que pouco ou nada fogem de
4. Seria importante frisar aqui que, fora do âmbito "erudito" do modernismo (encabeçado por seus poetas, escritores, artistas plásticos, arquitetos, etc.), houve uma fotografia igualmente voltada para a configuração e exaltação da paisagem humana brasileira. Refiro-me aqui, à produção fotográfica de Jean Manzon para a revista O Cruzeiro, objeto de tese de doutoramento defendida recentemente na FAU-USP por Helouise Costa. Ver: HELOUISE COSTA. Um olho que pensa.Tese de Doutoramento.S ão Paulo, Faculdade de Arquitetura e Urbanismo da Universidade de São Paulo, 1999. 2 vols.

5. TELÊ ANCONA LOPEZ. "As viagens e o fotógrafo". In Mário de Andrade, fotógrafo e turista aprendiz. São Paulo, IEB/USP, 1993

\section{J. TOLEDO.}

Flávio de Carvalho: o comedor de emoções. São Paulo, Brasiliense, Campinas, SP, Editora da Universidade Estadual de Campinas, 1994. 
7. Entrevistas republicadas no catálogo da exposição "Flávio de Carvalho 100 anos de um revolucionário romântico" com curadoria de Denise Mattar apresentada no CC Banco do Brasil ( 5 de agosto a 26 de setembro de 1999), Rio de Janeiro e no Museu de Arte Brasileira da Faap (20 de outubro a 29 de novembro de 1999), São Paulo.

8. WALTER ZANINI. Rego Monteiro: artista e poeta, 1899/1970. São Paulo, Empresa das Artes/Marigo Editora, 1997, p. 30-31.

9. Idem, p. $274-275$. um mero caráter documental. Talvez a mais interessante das fotos publicadas no livro citado seja o auto-retrato produzido pelo futuro artista aos 16 anos, em 1915. Realizada em frente ao espelho, quando Flávio de Carvalho ainda vivia em Londres, essa foto revela a imagem de um jovem curioso com o processo de fixação da própria imagem, ao lado do aparato fotográfico.

No entanto é preciso afirmar que o interesse de Flávio de Carvalho pela fotografia se estendeu também pelas suas preocupações mais gerais com relação à arte na modernidade. Tais preocupações ficam evidentes na série de entrevistas com intelectuais e artistas internacionais que Carvalho realizou em 1935 para o jornal paulistano Diário de São Paulo, com Tristan Tzara (onde salienta o fato da formação de Tzara como fotógrafo) e com Man Ray, um dos principais artistas da fotografia do século $\mathrm{XX}^{7}$.

Um outro artista modernista que parece ter se dedicado com maior afinco à fotografia, foi Vicente do Rego Monteiro. No primeiro capítulo de seu livro sobre o artista, Walter Zanini apresenta algumas fotos feitas por Monteiro nos anos 20, em Paris e, entre elas, uma fotomontagem ${ }^{8}$.

Nota-se nessas imagens que Monteiro possuía apreciável domínio de composição e das técnicas fotográficas, indicando uma certa prática nesse campo. No mesmo livro, Zanini apresentaria fotos realizadas pelo artista, nos anos $30^{9}$. Nessas fotos produzidas em Pernambuco, Rego Monteiro salientará um forte apego a imagens de caráter documental, sendo que, em alguns casos, conseguirá demonstrar uma subjetividade bastante particular ao documentar seu estado natal.

Excetuando esses exemplos bastante frágeis para configurar um corpus de real significação, o uso da fotografia por artistas e intelectuais modernistas ficou confinado, até muito recentemente, a duas contribuições muito específicas, ligadas à fotomontagem. Refiro-me às fotomontagens do poeta e pintor Jorge de Lima, realizadas entre os anos 30 e 40, e àquelas do artista plástico Athos Bulcão, cujas produções remontam à primeira metade dos anos 50 .

Mais recentemente, tornou-se público que Alberto da Veiga Guignard -respeitado como um dos principais pintores modernistas-, igualmente ocupouse da fotografia, mais especificamente, da fotomontagem. Dentro dessa escassez de produções fotográficas no âmbito modernista, parece-me no mínimo curioso o fato das produções daqueles modernistas que mais se dedicaram à fotografia gravitarem em torno da fotomontagem. Em torno de uma fotomontagem, diga-se, fortemente vinculada ao surrealismo - tendência, como será visto, pouco aceita no âmbito do modernismo.

Creio que uma análise um pouco mais detalhadada desta questão poderia ajudar a entender não apenas a produção desses três artistas mas, 
sobretudo, o próprio caráter marginal que elas assumiram, tanto dentro do quadro do modernismo, quanto de suas próprias obras, como um todo.

Antes, porém, de estabelecer essas considerações, creio que seria conveniente relatar, de maneria bastante sintética, o surgimento da fotomontagem no âmbito das vanguardas européias, com o intuito de estabelecer alguns parâmetros para a discussão que pretendo levar aqui.

Para a estudiosa inglesa Dawn Ades, no contexto do dadaísmo berlinense, no final da Primeira Grande Guerra, o uso da fotomontagem fazia parte da reação daquele grupo de artistas - ou anti-artistas -, contra a pintura a óleo, que seria "essencialmente única, particular e exclusiva"

Elemento de contestação ao aparente caos da realidade em constante transformação do período entre as duas grandes guerras, a fotomontagem foi um método de criação e uma nova modalidade de expressão que, ao mesmo tempo, incorporava decididamente os elementos da nova realidade tecnológica que tomava conta do cotidiano - e a fotografia era o ícone máximo dessa realidade nova -, servindo igualmente para opor a produção dos dadaístas à produção burguesa de arte, fosse ela convencional ou moderna.

Quando se refere à fotomontagem, Aaron Scharf afirma que tal método foi usado pelos dadaístas para atacar o realismo convencional da pintura (e das belas artes em geral, pode-se dizer), com o próprio realismo ${ }^{11}$. Por outro lado, Ades afirma que o uso da fotomontagem foi levado a cabo, tanto pelos dadaístas berlinenses quanto pelos construtivistas russos, igualmente como uma alternativa às limitações apresentadas pela pintura abstrata das vanguardas históricas, "sem retornar à pintura figurativa." ${ }^{12}$

As fotomontagens dos dadaístas de Berlim e dos construtivistas russos possuíam como característica comum uma dimensão ética e estética extremamente conectada com o desejo de romper com os velhos estatutos da arte burguesa (mesmo aquela ligada à vanguarda anterior à Primeira Guerra), e abraçar, como elementos constitutivos da própria obra de arte (ou anti-arte), os elementos surgidos no contexto da sociedade industrial de massa.

Os dadaístas berlinenses visavam, com suas fotomontagens, igualmente, atacar e satirizar os desmandos da sociedade e da política burguesas que trafegavam nitidamente para o apogeu da Alemanha nazista. Os construtivistas soviéticos, por sua vez, enxergavam a fotomontagem como uma ferramenta para a divulgação/implantação definitiva do socialismo, ao mesmo tempo que a percebiam como uma arte nova, ao alcance das massas.

Do ponto de vista formal, uma característica bastante presente nas fotomontagens produzidas pelos dois grupos é o aspecto planar que quase sempre assumem suas produções, fragmentadas, abusando das linhas de força do
10. DAWN ADES.

Photomontage.

London, Thames and Hudson, 1996, p. 13.
11. AARON

SCHARF. Art and

Photography.

London, Penguin

Books, 1974, p. 279

12. DAWN ADES.

Op. Cit. p. 15. 
plano (sobretudo as diagonais), as fotomontagens construtivistas e dadaístas apresentavam como herança imediata (e talvez não desejada), o esforço da pintura moderna, desde o pós-impressionismo, em romper com a ilusão de tridimensionalidade. Satírica ou apologética, elas sempre buscavam uma decodificação rápida de sua mensagem pelo observador, preferencialmente um indivíduo componente da massa trabalhadora.

Se as fotomontagens dadaístas e construtivistas partilhavam essas semelhanças e diferenças, já a fotomontagem de caráter surrealista apresentava propriedades bastante singulares. Ainda é Dawn Ades quem chama a atenção para o fato das fotomontagens ligadas à estética surrealista não se utilizarem com freqüência - ou pelo menos de se utilizarem de maneira menos óbvia -, das profundas mudanças de escala, tão comuns nas fotomontagens dadaístas. Segundo a autora:

"Disjunções e deslocamentos ocorrem [no caso da fotomontagem surrealista] dentro de uma cena "real"... ao contrário da fragmentação presente na colagem ou na fotomontagem dadaísta, há uma aparente continuidade de espaço [na colagem e fotomontagem surrealista]..."

Essa diferença, bastante visível nos dois tipos de fotomontagens, leva a algumas considerações que talvez ajudem a entender as diferenças entre o dadaísmo berlinense e o construtivismo russo em relação à produção surrealista. Os dois primeiros movimentos estavam fortemente marcados pela necessidade do embate com a realidade circundante, seja através do processo de incorporação de materiais típicos de uma sociedade de massa para a efetuação dos trabalhos (imagens retiradas de jornais, revistas, catálogos de lojas, etc.), seja pela escolha de questões cotidianas para discutir em suas produções.

O artista surrealista, por sua vez, agia de maneira contrária. Ao invés do embate com a realidade caótica e fragmentária da vida contemporânea, ele voltava-se, à procura da liberdade, para a sua realidade interior. Assim, criava num espaço quase sempre contínuo e sem fissuras - um universo que, embora sempre inquietante e repleto de personagens misteriosos, repousava num clima onírico, acima de qualquer circunstância mais prosaica. Se as fotomontagens dadaístas e construtivistas tinham como intuito atrair em primeiro lugar a massa de cidadãos das grandes cidades - conscientizando-a dos dilemas e circunstâncias de seu presente histórico -, as fotomontagens surrealistas parecem sempre se dirigir, antes de mais ninguém, ao próprio artista, o primeiro e principal observador de sua própria subjetividade destacada (pelo menos teoricamente) de qualquer coerção do consciente.

Em resumo: se a fotomontagem dadaísta e construtivista (esta última mais do que a primeira) buscou sempre a total comunicação com o observador 
anônimo das grandes cidades, a fotomontagem surrealista tinha como princípio a própria incomunicabilidade, o desejo sempre manifesto de não dar-se totalmente a ninguém (mesmo a seu autor, mero "aparelho" de uma inteligência às vezes atávica).

Estabelecida essa sintética definição da fotomontagem dentro do dadaísmo berlinense e do construtivismo, pontuando suas diferenças em relação à fotomontagem surrealista ${ }^{14}$, creio que seria interessante voltar, agora, ao contexto modernista brasileiro.

Se forem analisadas algumas das fotomontagens de Alberto da Veiga Guignard, Jorge de Lima e Athos Bucão, será visto que elas se enquadrariam no campo da fotomontagem de derivação surrealista, sobretudo aquelas concebidas e produzidas por Max Ernst. Nelas será vista a mesma inquietante procura de criação de espaços oníricos, lugares improváveis, onde figuras estranhas colocam-se como personagens de alegorias quase impossíveis de serem decodificadas objetivamente. Na fotomontagem "Sem título", de Alberto da Veiga Guignard, no primeiro plano, à direita, percebe-se as velas de uma embarcação sobre a água, encimadas por um vestido de mulher em movimento...

$\mathrm{Na}$ parte esquerda, um cogumelo formado por uma explosão e, ao fundo, dominando a cena, um rosto de perfil, cujo olho esquerdo, atônito, domina a cena estranha... Essa e outras fotomontagens de Guignard nunca foram estudadas, quer no quadro geral da obra do pintor, quer no âmbito do modernismo.

O que é possível dizer, numa primeira aproximação, é que, apesar de ter sido realizada no final dos anos 40, (aliás, como as outras duas fotomontagens conhecidas do artista) tal trabalho está extremamente vinculado à produção pictórica do artista, entre os anos 20 e 30, período em que Guignard voltava seu interesse para o surrealismo, influenciado por Ismael Nery.

Embora faltem estudos sobre essa fase da obra do pintor, se forem analisadas pinturas como "Sonho do poeta", realizada em 1933, será possível estabelecer conexões entre a produção de Guignard e a de Ismael Nery: temática de caráter "onírico"; forte linearidade constituindo as figuras da composição; predominância de uma configuração planar da obra... As mesmas características que aparecem na fotomontagem em questão e na última fase da pintura de Guignard...

Tais características que, de maneira geral, envolvem a primeira fase brasileira do artista e, igualmente, suas últimas produções, possibilitam levantar a seguinte hipótese: a produção de fotomontagens levada a cabo pelo artista não deve ter servido como mero passatempo mas, de alguma maneira, ajudouo, na verdade, a configurar certos elementos formais que marcariam sua obra, sobretudo o seu interesse pela exploração do plano pictórico.
14. Antes de estabelecer as diferenças entre esses dois tipos de fotomontagens, na verdade, o mais correto seria, talvez, estabelecer melhor as diferenças, às vezes cruciais, entre a fotomontagem dos dadaístas de Berlim e aquela dos construtivistas russos. No entanto, como essa questão ampliaria demais os propósitos deste texto $e$, de maneira nenhuma, contribuiria para a análise das experiências modernistas brasileiras no campo da fotomontagem, talvez as semelhanças aqui assinaladas entre as fotomontagens dadaístas e construtivistas, em contraposição às características da fotomontagem surrealista, sirvam para a compreensão do objeto de interesse deste texto. Para quem possuir como objetivo aprofundar seus conhecimentos sobre a fotomontagem na União Soviética e suas diferenças em relação à fotomontagem do Dada berlinense, recomendaria a leitura do ensaio de BENJAMIN BUCHLOH, "From Faktura to Factography", publicado em: ANNETTE MICHELSON. (et. alii.). October: the first decade, 19761986. Cambridge Massachussets/London, England, The MIT Press, 1987. p.76-113. 
15. FREDERICO MORAIS. Guignard. Rio de Janeiro, Museu de Arte Moderna do Rio de Janeiro / São Paulo, Novo Mundo, 1974, p. 32

16. Outros dados sobre as fotomontagens de Alberto da Veiga Guignard poderão ser encontrados no texto "Outro Guignard?", deste autor, publicado no catálogo da exposição "Apropriações / Coleções", realizada entre 30 de junho e 29 de setembro de 2002

(Porto Alegre, Santander Cultural, 2002, p. 93 e segs.).

17. A.M. PAULINO Jorge de Lima. São Paulo, EDUSP, 1995.
É importante observar, no entanto, que as fotomontagens de Guignard, embora detenham um profundo espírito de caráter surrealista, formalmente não se assemelham de maneira direta àquelas de Max Ernst, pois nelas o espaço não se demonstra contínuo e sem fissuras, como naquelas do artista alemão. Sobretudo na primeira delas, é notável como o caráter planar da obra sobressai frente a certas ilusões de profundidade.

Por outro lado, ainda tentando trazer novos dados para se pensar a influência inicial de Ismael Nery sobre o Guignard recém-chegado de seu estágio europeu, cumpre chamar atenção para o fato dos dois artistas terem tido amigos em comum, o que, como alertou Frederico Morais, "deve ter proporcionado várias oportunidades de diálogo" ${ }^{15}$. Um desses amigos em comum, o poeta Murilo Mendes, por sua vez - e como será visto -, irá prefaciar, nos anos 40, o livro de fotomontagens de Jorge de Lima - o que sugere outros pontos de estudo sobre a questão da fotomontagem dentro do contexto do modernismo brasileiro $^{16}$.

Na fotomontagem "Julgamento do tempo", de Jorge de Lima, realizada nos anos 30, é possível visualizar, à esquerda, no primeiro plano, uma coluna, cuja verticalidade é reafirmada e ao mesmo tempo subvertida pela estranha figura ao fundo, mais à direita: uma mulher, vestindo uma longa saia e um casaco com as mangas guarnecidas de pele. Da manga direita sai um estranho aparelho filiforme, de onde sobressai o rosto de uma mulher de cabeça para baixo, cujos cabelos pousam no solo.

Tal instrumento, por sua vez, é ligado a um tubo conectado ao capacete de um escafandro, que faz as vezes de cabeça da mulher de casaco com as mangas debruadas de pele... O caráter ascensional da coluna, ao mesmo tempo que é reforçado pela figura feminina de capacete, é subvertido pela mulher de cabelos longos, apontando para baixo...

Aquela figura mundana-subaquática recebe oxigênio da cabeça à sua frente, presa por elementos filiformes ao seu corpo...

As fotomontagens de Jorge de Lima seguem muito de perto o espírito das fotomontagens surrealistas, sobretudo aquelas criadas por Max Ernst: cenas insólitas ocorrendo em espaços quase sempre contínuos, oníricos, povoados de seres mutantes, misto de mulher e máquina, mulher e animal, mulher e manequim... Pouco estudadas, as fotomontagens de Jorge de Lima aguardam análises mais detalhadas e conclusivas, muito embora elas já tenham sido analisadas no contexto da obra poética do autor. A pesquisadora Ana Maria Paulino, em seu livro sobre o poeta ${ }^{17}$, garante, a certa altura de seu texto, o quanto a produção de fotomontagens influenciou a produção poética de Jorge de Lima, sobretudo para a elaboração de seu livro A invenção de Orfeu.

Apesar, no entanto, da importante contribuição de Ana Maria Paulino 
para uma melhor compreensão da obra de Jorge de Lima, como poeta, pintor e "fotomontador", é importante frisar que suas fotomontagens ainda podem ser objeto de mais reflexões sobre suas singularidades.

A fotomontagem "A invasão dos marcianos", realizada por Athos Bulcão em 1952, é mais uma mostra das raras fotomontagens realizadas no Brasil - esta já na segunda metade do século -, onde também é notável a herança surrealista: no primeiro plano uma figura masculina, com o rosto parcialmente coberto por sua mão, observa-nos por entre os dedos apenas com o olho direito. Logo atrás dele, um atleta, nu e de costas, está prestes a arremessar um objeto sobre uma grande metrópole, sobre a qual descem alguns pára-quedas...

O surrealismo "tardio" das fotomontagens de Athos Bulcão, por sua vez, levantam a possibilidade para se pensar na manutenção daquela tendência estética sempre dentro de um contexto marginalizado na produção brasileira, desde o apogeu do modernismo. Em plena década de 50, as fotomontagens de Bulcão tambem não se adaptam à visão grandiloqüente de brasilidade, visível nas pintura de Di Cavalcanti, Portinari e outros, ao mesmo tempo que, igualmente, não se adaptavam às preocupações formais dos novos grupos de artistas e intelectuais, ligados às tendências construtivas do período.

Não é do conhecimento de todos que o modernismo de viés hegemônico, ao qual nos referimos, não tinha muito apreço pelo dadaísmo e pelo surrealismo. Vertentes que, para dizer o mínimo, problematizavam o antigo entendimento da arte como forma de representação realista ou idealizada do entorno, elas não podiam ser aceitas por aquele grupo que via, na produção artística modernista, o potencial resgate ou redenção de uma noção um tanto abstrata de "realidade brasileira".

Numa carta escrita por Mário de Andrade a Prudente de Moraes, Neto, em 1927, fica evidente como, para Andrade, o surrealismo (que ele denominava "sobrerrealismo") não podia interessar para um movimento como o modernismo brasileiro:

\footnotetext{
(...) o sobrerrealismo é uma arte quintessenciada que me atrairia fatalmente si eu não tivesse dado uma função de acordo mais com a civilização e o lugar em que vivo. Porque incontestavelmente a civilização em que a gente vive aqui no Brasil não é a mesma dos franceses, não acha mesmo? (...) Considero o sobrerrealismo a conseqüência lógica de arte dum país que nem a França. No Brasil acho que no momento atual, pros que estão de deveras acomodados dentro da nossa realidade, ele não adianta nada. Não adianta porque não ajuda. Todas as questões que são de vida ou de morte pra organização definitiva da realidade brasileira(...) nos levam pra uma arte de caráter interessado que como todas as artes de fixação nacional só pode ser essencialmente religiosa (no sentido mais largo da palavra: fé pra união nacional, psicológica familiar social religiosa sexual)(...)

(...) Repare também que não articulo aqui nenhuma (sic) contradição de valor estético contra o sobrerrealismo. Tenho várias. Porém elas não importam agora. o que me importa é
} 
18. MÁRIO DE ANDRADE. Carta para

Prudente de Moraes Neto, de 25 de dezembro de 1927. In GEORGINA KOIFMAN (org.). Cartas de Mário de Andrade a

Prudente de Moraes,

Neto. 1924/36. Rio de

Janeiro: Nova Fronteira, 1985, p. 245 e segs.

19. MÁRIO ANDRADE,

"Fantasias de um poeta". In Suplemento em Rotogravura n.146, O Estado de São Paulo. 1a. Quinzena, nov.1939. Republicado em: Ana Maria Paulino (org.). O Poeta insólito: fotomontagens de Jorge de Lima São Paulo, Instituto de Estudos Brasileiros, Universidade de São Paulo, 1987, p. 9-10.

20. Idem, ibidem. não ver você marcar passo nem se manifestar seguindo uma fadiga (considero o sobrerrealismo um fenome (sic) de fadiga aliás perfeitamente psicológica na França) que si voxê esta (sic) acomodado com a vida de aventura (...) em que a gente está vivendo aqui não tem lógica nem é conseqüência necessária ou natural... ${ }^{18}$.

Mais de dez anos passados, e tendo o seu modernismo já galgado um posicionamento plenamente institucionalizado na cultura oficial do país, Mário de Andrade podia perceber agora o surrealismo como uma (positiva) manifestação das "nossas tendências mais recônditas”. É pensando, pois, num surrealismo já totalmente domesticado, preocupado apenas com o "eu", que o crítico irá se pronunciar, em 1939, sobre as fotomontagem de Jorge de Lima:

(...) a fotomontagem é um processo de expressão lírica. As nossas tendências mais recônditas, nossos instintos e desejos recalcados, nossos ideais, nossa cultura, tudo se revela nas fotomontagens. E é mesmo natural que seja assim. Dentro de uma centena de imagens recortadas, que estejam a nossa disposição, dois temperamentos diversos fatalmente escolherão as imagens que lhes são mais gratas, descobrirão combinações diferentes, movidos pelas suas verdades e instintos... ${ }^{19}$.

Conhecedor dos textos surrealistas, Mário de Andrade, ao escrever essas suas impressões sobre o fenômeno, levanta já a possibilidade de se pensar o processo da fotomontagem como um desestruturador do conceito romântico de autor: o sentido mais recôndito do ser, o produtor da fotomontagem encontra no produto, depois de realizado. Não é ele, conscientemente, aquele que pressupõe um significado prévio, a ser demonstrado na obra... Esta questão fica já bastante visível quando, antes do parágrafo citado, Andrade, jocosamente, ao avisar o leitor para nunca produzir fotomontagens, afirma:

"A fotomontagem parece brincadeira, a princípio. Consiste apenas na gente se munir de um bom número de revistas e livros com fotografias, recortar figuras, e reorganizá-las numa composição nova que a gente fotografa ou manda fotografar. A princípio as criações nascem bisonhas, mecânicas e mal inventadas. Mas aos poucos o espírito começa a trabalhar com maior facilidade, a imaginação criadora apanha com rapidez, na coleção das fotografias recortadas, os documentos capazes de se coordenar num tom fantástico e sugestivo, os problemas técnicos da luminosidade são facilmente resolvidos, e, com imensa felicidade, percebemos que, em vez de uma pura brincadeira de passatempo, estamos diante de uma verdadeira arte, de um meio novo de expressão..."

Fica claro que, para Andrade, a fotomontagem é um processo lúdico, com suas regras, onde o autor é apenas um coordenador, aquele que dá condições para que os fragmentos de fotos se agrupem, e que consegue solucionar fortuitos problemas técnicos. O autor apenas rege significados latentes, possíveis.

Tais considerações demonstram como Mário de Andrade, mesmo percebendo a fotomontagem apenas como um passatempo, um espaço lúdico e 
capaz somente de trazer à tona questões pessoais latentes, já intui (e talvez essa seja, de fato, a melhor palavra para definir seu posicionamento), intui a possibilidade de se pensar o autor/artista como um produtor, alheio a qualquer pretensão prévia, antes de desenvolver seu trabalho.

No entanto, talvez seja justamente por perceber, na prática da fotomontagem, a substituição da figura do artista/autor especializado pela figura do produtor é que ele enfatiza apenas as características "extra-artísticas" da fotomontagem, deixando de lado a possibilidade de pensá-la, de fato, como uma modalidade artística procedente - apesar de declarar ser ela uma "verdadeira arte" ${ }^{21}$. Por outro lado, outra questão extremamente significativa nesse texto é que nele fica visível a consciência de se estar vivendo já no Brasil - pelo menos na esfera social onde o autor se enquadrava -, um cotidiano mediado por imagens reproduzidas pelos meios de comunicação de massa ( "... consiste na gente se munir de um bom número de revistas e livros com fotografias...”), cercado, igualmente, das facilidades dos aparatos tecnológicos, sempre à mão (“... reorganizá-las numa composição nova que a gente fotografa ou manda fotografar...). Mas, apesar de toda essa nova realidade que as fotomontagens parecem apresentar para o autor e do seu reconhecimento como uma "verdadeira arte", ele estava consciente que esse processo de produção artística não encontrava muitos adeptos no Brasil. Ao se referir especificamente às obras de Jorge de Lima, Andrade afirma:

"Esta página apresenta algumas fotomontagens do poeta Jorge de Lima. Talvez não seja grande elogio afirmar que o poeta... é o maior criador de fotomontagens que temos no Brasil. Porque estes ainda são tão poucos que não é grande mérito ser o maior deles... ${ }^{22}$

A pergunta que é possível fazer é a seguinte: Por que no Brasil, no final dos anos 30, os adeptos da fotomontagem eram tão poucos? Afinal, por mais acanhada que fosse a sociedade de massas no Brasil naquela época, não resta dúvida (como bem demonstra o texto de Andrade) que quem desejasse produzilas encontraria farto material impresso no país...

De qualquer maneira, a produção de fotomontagens não colou no Brasil modernista, quer como mero passatempo, quer como manifestação artística autônoma. Ou melhor: se a fotomontagem colou enquanto passatempo, enquanto jogo quase pueril, isto não é possível afirmar, uma vez que não se possui documentação sobre o assunto.

No entanto, como já foi afirmado aqui, no campo da arte, ela com certeza não se afirmou. Retirando as já citadas produções de Jorge de Lima, Guignard e Athos Bulcão, essa modalidade de produção artística não se firmou no país. As razões para a inexistência de fotomontagens no âmbito da arte modernista brasileira poderiam ser encontradas, justamente, na ausência de uma presença efetiva de uma arte erudita de fundamentação burguesa no campo da
21. Perceber a distinção entre autor/artista e produtor no texto de Mário de Andrade só foi possivel tendo em mente o ensaio "O autor como produtor", de Walter Benjamin, texto de uma palestra proferida pelo filósofo em Paris, em 1934, onde fica estabelecida uma distinção muito clara entre o autor (concebido dentro dos valores românticos e burgueses) e o produtor, um novo protagonista, nascido da nova ordem sócio-política do socialismo. Não foi possível detectar se Andrade teria tido acesso a esse pensamento de Benjamin. No entanto é visível que o autor brasileiro, mesmo percebendo o surgimento desse novo protagonista que elabora as fotomontagens sem ser propriamente o seu "autor" (pensamento extremamente próximo daquele do filósofo alemão que nutria sobre a fotomontagem a compreensão de ser ela uma nova forma de arte revolucionária), não concorda e nem parece desejar que o "produtor" substitua o "autor", demonstrando que, apesar da acuidade de seu pensamento, o crítico brasileiro possuía limites muito claros. (FLÁVIO R. KOTHE, (org.). Walter Benjamin. São Paulo, Editora Ática, p. 187 e segs.

22. Idem, ibidem. 
sociedade brasileira, contra a qual a produção de fotomontagens poderia dirigir-se.

Apesar do forte componente plástico da produção popular, da constituição de um circuito de arte na antiga Capital Federal, nos moldes europeus, desde o início do século XIX, da existência de cursos de arte erudita em algumas capitais do país, do crescimento do número de artistas e de circuitos legitimadores da arte burguesa... todos esses dispositivos não foram suficientes para criarem no Brasil uma presença efetiva da arte erudita de fundamentação burguesa e conservadora, capaz de fazer com que as novas gerações se insurgissem contra ela por intermédio de práticas artísticas e estéticas que desestabilizassem sua hegemonia dentro do quadro social.

As artes visuais transitavam em grupos tão restritos do corpo social brasileiro, durante o século XIX e início do seguinte que era como se elas, de fato, não existissem como questão cultural. Um dado que talvez ajude a entender melhor este problema seria a própria ação de alguns modernistas brasileiros. À suposta supremacia da arte de teor acadêmico/burguês do século XIX e início do século seguinte, os modernistas, na verdade, não propuseram nenhum rompimento estrutural, baseado na ação ligada às vertentes mais radicais da arte de vanguarda.

Assim como a fotomontagem, entendida como atitude desestruturadora dos conceitos mais conservadores da arte burguesa, não tece um florescimento real no Brasil durante todos os primeiros 50 anos do século $\mathrm{XX}$, aqui igualmente não proliferou nenhuma produção conseqüente no campo da pintura e da escultura não-figurativa. Isso para não fazer referência às investidas mais desestruturadoras, ligadas à desmaterialização pura e simples da arte, apesar da presença marcante - e totalmente solitária - de Flávio de Carvalho.

Pelo contrário: ignorando toda produção artística burguesa do século anterior e dos primeiros anos do século XX no Brasil, os modernistas propuseram uma linha de conduta para a arte brasileira onde as manifestações privilegiadas deveriam ser a pintura e a escultura (duas modalidades consagradas pela cultura burguesa ocidental). Mas uma escultura e uma pintura que, mesmo experimentando certos estilemas vanguardistas, deveriam ficar restritas aos limites da figuração da paisagem física e humana do país, sem nunca enveredar por especulações rumo a soluções não-figurativas.

Muito mais ligados às vertentes conservadoras do retorno à ordem internacional do que - como querem muitos - às vanguardas internacionais do início do século -, foram os modernistas os responsáveis pela instauração definitiva de uma arte burguesa entre nós, onde o enraizamento com o tecido social brasileiro apenas se dava através do tema e/ou das cores "brasílicas". Pode-se dizer, inclusive, que, no ar rarefeito da arte brasileira do início do século XX, os modernistas - salvo raras exceções -, acreditavam na arte moderna apenas em 
suas possibilidades pedagógicas, no sentido de criar instrumentos para uma suposta compreensão do país, na verdade, dentro dos moldes mais legítimos da arte burguesa do século XIX.

No texto citado de Mário de Andrade, por mais que se possa reconhecer sua consciência sobre o que a fotomontagem poderia significar em termos de uma nova estética e de uma nova posição do artista criador, não resta dúvida que nem lhe passou pela mente manifestar o caráter potencialmente deflagrador que a fotomontagem poderia ter assumido na construção, de fato, de uma nova arte no Brasil. Pelo contrário: além de perceber na fotomontagem seu potencial de satisfação lúdica do produtor, ele aponta o caráter didático que ela poderia assumir para o leigo entender "certas doutrinas" da arte moderna:

“... A fotomontagem é uma espécie de introdução à arte moderna. Ainda há muita gente que não sabe olhar um quadro de Picasso ou um desenho aquarelado de Flávio de Carvalho.

Mas toda pessoa que se mete a fazer fotomontagens, em pouco tempo fica habilitada a entender certas doutrinas artísticas da atualidade e a distinguir o que há de valor técnico num quadro cubista e o que há de subjetividade psicológica e sonhadora no Sobre-realismo..."

Este trecho demonstra que Mário de Andrade parecia perceber as manifestações artísticas mais radicais, quer no Brasil, quer lá fora, como puras doutrinas estéticas, voltadas para si mesmas, sem nenhum entranhamento real na luta para a transformação da sociedade daquela época. Sem um quadro de debate real sobre as manifestações artísticas e estéticas brasileiras e internacionais, nosso maior crítico de arte do período não se dá conta - ou prefere não se dar conta - das potencialidades desestruturadoras da fotomontagem, privilegiando apenas seus aspectos mais pueris.

No entanto, em 1943, algumas daquelas fotomontagens produzidas por Jorge de Lima foram reunidas e publicadas em livro, cujo título é o seguinte: Pintura em pânico.

É interessante que a publicação do poeta faz referência à pintura, que estaria em pânico. Muito embora tal título deva ser conseqüência do título de um livro que Jorge de Lima e Murilo Mendes escreveram em 1938 - Poesia em pânico -, não resta dúvida que, ao publicar seu livro de fotomontagens com o título citado, não deixa de indicar que o autor devia possuir a consciência do que a fotomontagem poderia representar para o devir da arte na sociedade burguesa: a desestruturação do conceito de arte como obra única, realizada por um autor determinado a partir da concepção de formas originais. As fotomontagens de Jorge de Lima, mesmo fiéis ao ideário já, de alguma maneira, consagrado pelos surrealistas europeus, guardavam - pelo menos potencialmente o desejo de desestruturarem, ou ajudar na desestruturação da lógica burguesa, apresentada na pintura como única modalidade "digna" de arte visual. Muito 
23. MURILO MENDES.

"Nota Liminar". In: JORGE DE LIMA,

Pintura em Pânico.

Rio de Janeiro, Tipografia

Luso-Brasileira, 1943.

Repubicado em A. M

Paulino (org.). JORGE DE

LIMA, O poeta

insólito.... p. $11-12$.

24. Idem, ibidem.

25. Idem, ibidem importante, inclusive, o fato de tê-las publicado em forma de livro, porque, com essa atitude, o poeta assumia o próprio conceito de reprodutibilidade presente na foto e que ficaria completamente esmagado, ou sem efeito, caso as fotomontagens permanecessem como objetos únicos.

Mas a própria compreensão dessas intenções de Jorge de Lima não é absorvida com tranqüilidade pelo meio intelectual brasileiro, mesmo por aqueles mais próximos do artista. Se for lido com atenção o texto que o poeta Murilo Mendes escreve para o livro de Lima, à guisa de prefácio - "Nota liminar"-, será visto que Mendes oscila entre o caráter pedagógico que a fotomontagem poderia ter (talvez influenciado pelo texto de Mário de Andrade, anterior ao seu), e o caráter desestruturador da mesma. A certa altura do texto, Murilo Mendes afirma:

“... O livro de Jorge de Lima: não é apenas seu aspecto feérico e arbitrário que nos interessa mas também seu aspecto educativo. O hábito de recortar gravuras, desarticular elementos e depois dar-lhes unidade, poderá contribuir poderosamente para desenvolver a sensibilidade plástica de todos, a começar pelas crianças...”. ${ }^{23}$

Na seqüência desse pensamento, no entanto, percebe-se que Mendes vai articulando o raciocínio sobre a capacidade devastadora que a fotomontagem poderia assumir, dentro de um contexto mais alargado do fazer artístico, não mais restrito às elites: “... A fotomontagem é absolutamente inspirante. Não se destina apenas a uma elite de refinados. Tenho observado a fascinação que exerce mesmo sobre pessoas incultas de várias classes...”. ${ }^{24}$

Nota-se, no texto de Murilo Mendes, uma concatenação de idéias cujo siginificado manifesto não parece se coadunar com um discurso produzido de maneira linear. De alguma maneira, o poeta usa de alguns artifícios ligados à natureza da fotomontagem. Percebe-se essa característica na continuidade do texto:

“... Há uma combinação do imprevisto com a lógica. E a fotografia tem ajudado o homem a alargar sua experiêcia da visão. O pânico é muitas vezes necessário para se chegar à organização. A marcha de todos os movimentos de revolta deste século acelerou a compreensão dialética que dormia nas poltronas das academias. Entretanto, ei-nos chegados a Guernica...”

Percebe-se aqui como Murilo Mendes vai introduzindo a questão da arte moderna, como uma estratégia de desestruturação do estabelecido. A premissa ainda é a pintura moderna em relação aos problemas sociais e políticos do momento (Guernica, de Pablo Picasso). Em seguida, será a fotomontagem:

“... Demonstrar a burrice, o tabu dos materiais ricos, desarticular o espírito burguês em todos os seus setores, organizar a inteligência e a sensibilidade; atingimos enfim a inevitável transfiguração do elemento social e político. Movimentos paralelos: revolução política, revolução estética... ${ }^{25}$. 
Murilo Mendes, nessa real introdução à questão da fotomontagem no Brasil (superando, assim, o papel instrumental de seu texto de apenas introduzir as produções de Lima), vai conferindo a ela o papel que poderia e deveria desempenhar dentro da cena contemporânea:

\footnotetext{
"Em cada homem se processa a formação, o desenvolvimento e o fim. E o fim só pode ser a vitória, mesmo que se apresente sob as aparências da derrota. "As catacumbas marinhas contra o despotismo", "Mora a reação, a poesia respira”, além de outras, são imagens de um mundo que resiste à tirania, que se aparelha contra o massacre do homem, o aniquilamento da cultura, a arte dirigida e programada. A fotomontagem implica uma desforra, uma vingança contra a restrição de uma ordem do conhecimento. Antecipa o ciclo de metamorfoses em que o homem, por uma operação de síntese de sua inteligência, talvez possa destruir e construir ao mesmo tempo" 26
}

26. Idem, ibidem.

Em que pese o caráter ingênuo dessa visão transformadora que a arte destituída de todos os entraves da tradição poderia vir a assumir, não resta dúvida que foi Murilo Mendes quem, ao que parece, mais perto chegou no Brasil da compreensão das potencialidades da fotomontagem.

As relações da arte brasileira, tanto com a fotomontagem quanto com o próprio legado surrealista internacional, se tornarão mais intensas a partir dos anos 60, ganhando soluções muito interessantes - tanto num caso, como no outro -, sobretudo a partir da década seguinte.

A apropriação de imagens pré-existentes - a base da fotomontagem e aquela já clássica definição da beleza surrealista - "tão belo quanto o encontro de um guarda-chuva e uma máquina de costura numa mesa de operação” sobretudo quando unidos (mas não apenas), estarão presentes em importantes poéticas de artistas brasileiros da segunda metade do século XX. Seria a vitória tardia das correntes desestabilizadoras da "verdade modernista" por ela rechaçadas na primeira metade do século passado? Muito boa pergunta que, infelizmente, não poderá ser respondida aqui. 